\title{
Birth of a "respectable" discipline : from Kant to new epistemological imperialism. On the early history of computer science.
}

\author{
Camille Akmut
}

March 11, 2020

\begin{abstract}
How does one establish a science as a respectable discipline? The first decades of computer science; and, from Kant's conceptions of philosophy as queen discipline to a new kind of scientific imperialism : science of everything.
\end{abstract}


Retranscription of a talk : I spoke freely for 40 minutes until I had nothing left to say. This is the excerpted, annotated result.

\section{Modest beginnings : a sense of oneself's worth}

The real history of [computer science], you will not find on the pages of the ACM... It is not in its interest either. (...)

A period when computer science [lacked an identity] ...

Computer science had been done before. By logicians. It was not called computer science, then. Not quite. People like Alan Turing, Church, and all these other logicians around Princeton, and other institutions.

[They] had not come together, as computer scientists [yet]. They had not "unionized", in a way.

This only really happened in the '50s, '60s; which is when the Turing Award was created [among other things].

During that period computer scientists were very much concerned with establishing their new discipline as a - respectable - scientific discipline.

And, it is only if we make that hypothesis that the Turing Award [comes in and] makes sense [among others].

A very young, juvenile discipline in search of respectability.

Respectability : creating limits from other, neighboring sciences, e.g. mathematics. Computer scientists wanted to establish [a series of facts] : "We are not mathematicians", "We are a new, separate discipline!", "We are not physicists!", "We are not electrical engineers" ...

In other words, the question is : How does one establish a discipline as a respectable scientific discipline?

Not as a pseudo science.

And, computer science, now, of course, is the new "queen discipline" of all disciplines...

In many, many ways, computer scientists now have the same ambitions that philosophers had, not too long ago.

Of wanting to explain all other disciplines.

These are ambitious people.

And, it would be easy to draw parallels with the history of philosophy.

It was in [the foreword of the first edition of] 'Critique of Pure Reason' that Kant was melancholic about philosophy (i.e. metaphysics) once being the "queen" of all disciplines.

"Es war eine Zeit, in welcher sie die Koenigin aller Wissenschaft genannt wurde..." 
[But, first : ] How does one establish a science as a respectable discipline?

(Just by asking all of these questions we come much closer to the real, social history of computer science.)

One way was, of course, to establish institutions.

\section{Institutions}

[They] establish[ed] institutions, create[d] departments, create[d] faculties... of computer science! Not, "divisions" within mathematics departments [merely, as was the case previously]. But, completely separate - [this is meant] in the most physical sense. Rooms, separate rooms, separate buildings.

Separate titles : "computer scientist", "computer science", etc. ...

So : one way computer scientists were able to do this, [i.e. : becoming themselves], was [by] creating new physical spaces.

[To new mental structures would correspond new infrastructures.]

So, that - in their heads - their notions of being separate identities would be matched in reality, too...

There were other ways.

\section{The theoretical "front"}

One thing that was very fashionable during this period was writing articles called "What is computer science?"

This was the great fashion [at the time]. The '60 and '70s...

Everyone wrote their own "What is computer science?" [essay].

Including very prominent figures. Including Turing Award winners...

One popular definition was: "Computer science is the science of phenomena around computers".

And, so everyone answered the same question [differently], but what they had in common was, again : computer science is its own discipline.

It is not biology. ... It not the same as other disciplines. [Instead, a discipline] with its own rules, it own objects, with its own methods;

Warranting the creation of a new science.

All those debates are now a little bit forgotten, but now it would occur to no one to doubt computer science as a real discipline.

But, this was very different only sixty years ago, when computer scientists seemed to feel an inferiority complex, and were very industrious when it came to [answering] "No, we are real scientists."

Giving respectability to computer science happened in many ways. Other people fought on other fronts :

Another vector was education. 


\section{The issue of the curriculum}

There were other people who thought "now, we also need to create diplomas, [degrees,] we need to create computer science courses", and;

"how will they look?", "what content will we give [to] them?"

This was a third or fourth way by which computer scientists gave a body, and a respectability, to their science.

They must have obviously felt it was lacking.

Compare with mathematics or physics, which had existed for hundreds and hundreds of years including as "constituted disciplines" inside universities...

Papers were released [by computer scientists] on this subject, also. The computer science curriculum.

George Forsythe, who was Donald Knuth's elder [if not mentor], was among them. At Stanford.

At other institutions people did the same as well.

Purdue is worth mentioning. Purdue was the first computer science department in the United States [according to writings by members of that institution].

Forsythe for a while seemed to defend the notion that Stanford was first.

Voices from these prestigious institutions are often amplified, and carry further with the wind than others...

\section{Symbolic power : a scientific prize}

When we reconstitute this social context, we understand now what the role of the Turing Award was. What its function was. The very same.

The purpose remained the same :

To give [a young discipline,] computer science some prestige.

Just like the Nobel Prize had done for other disciplines, the Turing Award would now do for computer science. Using the same means.

[A symbolic reward paired with] lots of money. Hundreds of thousands of dollars.

[This was to distinguish computer science just as much as the select computer scientists the prize was given to.]

[Given only to] those judged "worthy". 


\section{Conclusion}

Thus the worthy, "real" computer scientists were finally born : named, professionalized, spatialized, consecrated even.

But, the judges rewarded their own good judgment.

And, as with Greek art, we are inclined to think that the beauty of this new geometry may lie with the beholder too...

Birth of a new reason. 
References.

Kant, E.. 1781. 'Kritik der reinen Vernunft'. First edition.

Collective. 19th c. onwards. 'Prosopographia Imperii Romani'.

[I talk about prosopography elsewhere in the talk.]

Canguilhem, G..'Ideology and rationality...'. Later edition.

["What Marx bestowed upon Greek art..."]

Hobsbawm, E.. 1994. 'The age of extremes'.

[A social historian writes of a "golden age" (ie. the post-ww2 period) : For blacks, gays, women, trans* people, it was the bronze age.

There was no golden age for poor people, because

for poor people there is never a golden age...] 